\title{
Multicultural Schools and New Demands on Leadership
}

\author{
Fred Carlo Andersen \\ Department of Teacher Education and School Research, Oslo University, Norway \\ Correspondence: Fred Carlo Andersen, Østfold University College, Norway.
}

Received: February 14, 2014

Accepted: March 7, 2013 Online Published: May 5, 2014

doi:10.11114/jets.v2i3.349

URL: http://dx.doi.org/10.11114/jets.v2i3.349

\begin{abstract}
The purpose of this study is to explore the Norwegian Government's expectations pertaining to new demands on leadership expressed in policy documents with regard to a multicultural society. Data from seven government's white papers were thematically analyzed with regard to knowledge, skills and attitudes. The study is framed within a theoretical approach, deriving from a tradition, promoting emancipatory pedagogies that arise from political and social movements, feminist perspectives, and critical pedagogy. Results indicate that there is a lack of a transformative movement that may produce critically thinking socially active minority students, deriving from critically thinking socially active school leaders and teachers. It is argued that there is too little emphasis on what kind of leadership competencies i.e. knowledge, skills and attitudes the school leaders must possess as their school populations become more and more linguistically and culturally diverse. The article concludes with possible implications for school leadership preparation programs.
\end{abstract}

Keywords: School leadership, linguistic and ethnic diversity, educational policy documents.

\section{Introduction}

Norway has since 1970 evolved from being a peripheral immigrant country in Europe to being a significant receiver measured relative to population size. Historically, inspired by social democratic politics for ensuring quality, Norway, like the other Scandinavian countries, has strongly been committed to comprehensive education and social justice. Thus, the countries have a conviction that a more democratic and egalitarian society is both possible and desirable, and that education can have an important role to play in attaining this kind of society. The development of the comprehensive school system in Scandinavia must be seen in connection with the unique tradition of consensus-seeking politics in education (Møller 2009a). In Norway the government will, through its education policies, reinforce the best aspects of the Norwegian community, and respond to the main challenges. Ensuring all students good learning conditions is a key to combating social inequality and to creating a more just society. The latest school reform in Norway, entitled the Knowledge Promotion (Norwegian Ministry of Education and Research 2006a), places increased focus on basic skills and knowledge through outcome-based learning. It seeks to improve learning outcomes by changing the contents, organization and structure of education programs in the compulsory and upper secondary education and training. Likewise it aims to offer differentiated learning that supports both individual adaptation and inclusion.

The purpose of this study is to explore the Norwegian Government's expectations pertaining to new demands on leadership expressed in policy documents with regard to a multicultural society. The study seeks to identify what expectations are assigned to school leadership through education policy documents pertaining to a multicultural society with regard to school leaders' knowledge, skills, and attitudes.

Politically, from the point of departure, the Knowledge Promotion has broad consensus among the political parties in Norway. It was initiated by a conservative coalition government, and the next government, another coalition, led by a social democratic party, decided to adopt the new reform without changing much of the content. One intention of the reform was to achieve a system change including clearer national goals, knowledge of results in a broad sense, clearer responsibilities, greater local freedom and a better support and guidance system (Sandberg \& Aasen 2008). The Organization for Economic Co-operation and Development (OECD) (2010) proposes several measures improvements of the education sector. Particularly relevant for the questions that I address in this study, is the suggestion that Norway needs to create an academic professional leadership environment for minority students. Hence, school leaders may get access to important new ideas and examples of best practice to encourage for change and improvement in education. Results from the Program for International Student Assessment (PISA) in 2000, 2003, and 2006 show that linguistic minority 
students (minority students) in Norway perform at a lower level in reading, maths and science than majority students (Hvistendahl \& Roe 2009). Likewise, the latest PISA results show that in maths, the difference between minority and majority students is more or less unchanged since 2003 (Kjærnsli \& Olsen 2013).

In Scandinavia school leaders are increasingly held accountable for school development and students' outcomes. At the same time they experience a situation of decreased authority within the school context with limited recourses (Møller 2009a). Although Norway has less difficulties than several other countries in Europe (OECD 2008), international studies report that school leaders' work load, and difficulties with recruiting school leaders have increased (ibid). Hence, it is recommended that the school leaders' responsibilities are revised, and that policy ensures that the students' learning and outcomes are emphasized in school leaders' practice (ibid). The White Papers that I investigate are supposed to express the government's expectations to school leaders' practice.

School leadership research in Norway often draws on Gronn's conceptualization of leadership (e.g. Møller 2009b). Gronn (2002) has defined leadership as:

a status ascribed to one individual, an aggregate of separate individuals, sets of small numbers of individuals acting in concert or larger plural-member organizational units. ... The individuals or multi-person units to whom influence is attributed include, potentially, all organization members, not just managerial role incumbents. Managers may be leaders but not necessarily by virtue of being managers, for management denotes an authority, rather than an influence, relationship....Finally, the duration of the attributed influence may be short or long term. (ibid:428-429).

This definition shows how the concept is closely related to a family of terms like authority, influence and power. It presupposes that leadership involves an inter-play between knowledge and action and that it is conscious of conditions and of change. Although this approach takes into account that leadership is not necessarily synonymous with a particular position, and that it may come from teachers or others, school leaders are increasingly held accountable for students' results and the realization of equity and inclusive education for all. The Norwegian Government has in several policy documents emphasized the role school leadership plays in all aspects of schooling. Likewise, research has highlighted the crucial position of school leaders.

\section{Literature Review}

Several (e.g. Robinson, Claire, Rowe \& Rowe 2008) emphasize the connection between leadership and the students' learning results. The more school leaders focus on their relations, their pedagogical work and their own learning about the core activities, the more influence they have on the students' learning results.

Multicultural schools expose extensive and challenging tasks which imply new demands for school leadership (Tolo \& Lillejord 2006). Experiences from decades of increased immigration indicate that one obvious specific challenge is that groups of minority students do not have sufficient linguistic competence in Norwegian. Notwithstanding, school leaders, from upper secondary school in particular, report that they lack the experience from language teaching for minority students, and that they do not have the necessary competence to implement the new subject Curricula in Basic Norwegian and Mother Tongue for minority students (Utdanningsdirektoratet, 2010). Moreover, school leaders report that they do not have sufficient resources and support from the school owner level. Elsewhere, the need to adapt the curricula and teaching methods to a culturally and linguistically diverse student body is emphasized (Ladson-Billings 1995, Nusche 2009, Andersen \& Ottesen 2011). Also, family background indicators play an important role in predicting students' achievement (Bakken 2009). Likewise, there is a continuous debate both among policy-makers, professionals and the public about the right ways to teach diverse student populations. Accordingly, questions ought to be raised about how to lead multicultural schools.

Within a Norwegian context, Tolo and Lillejord (2006) investigated the political dimensions with regard to leadership in multicultural schools by analyzing two policy documents, "Equity Education in Practice", a strategy plan for better teaching and greater participation of linguistic minorities in kindergartens, school and education (Norwegian Ministry of Education and Research 2007), and White Paper 30, "Culture for learning" (Norwegian Ministry of Education and Research 2004). The purpose was to find out how these documents may function as guidelines for the development of multicultural schools. Moreover, they asked what challenges school leaders may have when implementing the policy in school. They found that the responsibility for developing a pedagogical strategy to greater extent than ever before is placed on each local school. Consequently, they state, developing a multicultural school implies a politicizing of school leaders' tasks. Thus, school leaders need to concretize the aims for an equity school in dialogue with teachers, students, parents and other co-operators. In the current study the purpose is to identify what expectations the White Papers have with regard to school leaders' specific tasks along with three dimensions: knowledge, skills and attitudes. Rønning Haugen (2010) analyzed White Paper 16 (Norwegian Ministry of Education and Research 2006). She discussed the text in relation to two competing equity models in education: "equity through equality" and "equity through diversity." She 
analyzed how these models, or the combination of these, may be related to power and control. Results from the analysis claim that there is a lack of attention given to the diversity of students. As her study simply investigates one policy document, the current study widens the scope, drawing the attention to seven central policy documents from the last decade, relating to the latest curriculum reform in Norway. It also narrows the scope, as the analysis investigates what expectations are assigned to school leadership. Heldal Stray (2010) has investigated how democracy and citizenship are conceptualized in policy documents which lead to the new school reform (Norwegian Ministry of Education and Research 2002, 2003, 2004). I add to the field of knowledge, an investigation of White Papers produced after the reform. As yet, there are no studies within a Norwegian context that investigate ethnic and linguistic diversity and leadership more broadly. This lack of research shows the importance of the current study to the field of school leadership in particular and to the body of research in multicultural education in general. In this respect, the study might uncover some implications for school leadership programs. I formulate the research question as follows:

What expectations are assigned to school leadership through education policy documents pertaining to a multicultural society with regard to:

- $\quad$ knowledge, i.e. what a school leader is expected to know, know about, and understand.

- $\quad$ skills, i.e. what a school leader is expected to do and master.

- $\quad$ attitudes, i.e. what a school leader is expected to stand for, identify with, commit to, and signal.

\section{Theoretical Framework}

The theoretical approach is based on different literature and theories on school leadership which share the same epistemological point of departure, deriving from a critical tradition, promoting emancipatory pedagogies that arise from political and social movements, feminist perspectives, and critical pedagogy (Giroux 1994, McLaren 1995, Burbules \& Berk 1999, Blackmore \& Sachs 2007, Darder, Baltodano \& Torres 2009). The table 1 below, adopted from Shields (2010:563), illustrates distinctions between transformative and transformational leadership. It demonstrates deep differences between the two theories. The comparison is relevant, as transformational approaches have, in various ways, dominated the field of educational leadership for the past 30 years (Bass \& Aviolo 1994, Leithwood \& Jantzi 2005, Bass \& Riggio 2006). Briefly, transformational leadership focuses on improving organizational qualities, dimensions and effectiveness, while transformative leadership begins by challenging inappropriate uses of power and privilege that create or perpetuate inequity and injustice. The latter implies concentrating on more than what can be done, confined by a "best practice"-frame. Equally important, it concentrates on what should be done to achieve global inclusion, equity and social justice for everyone. The transformative approach raises questions about the purpose of education and leadership and about issues of social justice addressing social and economic inequality more broadly within democratic societies (Marshall \& Oliva 2006). The approach is inextricably related to inclusive leadership (Ryan 2006), social justice leadership (Theoharis 2007), advocacy leadership (Anderson 2009), and antiracist school leadership (Brooks \& Arnold 2013) which differ from several other theoretical approaches to leadership developed in the last few decades. I analyze the documents through the lenses of transformative leadership, and discuss how the objectives in the documents seem to meet both the academic and the social justice needs of a linguistically and ethnically diverse school.

Table 1. Distinctions between two theories of leadership, adapted from Shields (2010)

\begin{tabular}{|l|l|l|}
\hline $\begin{array}{l}\text { Starting } \\
\text { point }\end{array}$ & $\begin{array}{l}\text { Need for the organization to run smoothly and } \\
\text { efficiently }\end{array}$ & $\begin{array}{l}\text { Transformative leadership } \\
\text { Material realities and disparities outside the organization that } \\
\text { impinge on the success of individuals, groups, and } \\
\text { organization as a whole. }\end{array}$ \\
\hline Foundation & Meet the needs of complex \& diverse systems & Critique and promise \\
\hline Emphasis & Organization peep and equitable change in social conditions \\
\hline Process & $\begin{array}{l}\text { Understanding of organizational culture; setting } \\
\text { directions, developing people, redesigning the } \\
\text { organization, and managing the instructional } \\
\text { program }\end{array}$ & $\begin{array}{l}\text { Deconstruction and reconstruction of social/cultural } \\
\text { knowledge frameworks that generate inequity, } \\
\text { acknowledgement of power, and privilege; dialectic between } \\
\text { individual and social }\end{array}$ \\
\hline Key values & Liberty, justice, equality. & $\begin{array}{l}\text { Liberation, emancipation, democracy, equity, justice } \\
\text { Individual, organizational, and societal transformation }\end{array}$ \\
\hline Poal & Organizational change; effectiveness & $\begin{array}{l}\text { Positional, hegemonic, tool for oppression as well as for } \\
\text { action }\end{array}$ \\
\hline Leader & $\begin{array}{l}\text { Inspirational fooks for motive, develops common purpose, } \\
\text { focuses on organizational goals }\end{array}$ & $\begin{array}{l}\text { Lives with tension, and challenge; requires moral courage, } \\
\text { activism }\end{array}$ \\
\hline $\begin{array}{l}\text { Related } \\
\text { theories }\end{array}$ & $\begin{array}{l}\text { School effectiveness, School reform, School } \\
\text { improvement, Instructional leadership }\end{array}$ & $\begin{array}{l}\text { Critical theories (race, gender), Cultural and social } \\
\text { reproduction, Leadership for social justice }\end{array}$ \\
\hline
\end{tabular}


Despite the differences, transformative leadership and transformational leadership theories share some common roots. Both theories of leadership have at their heart the notion of transforming or changing something. Both terms have frequently been used synonymously and, without clarifying the distinctions, to describe educational leadership. Although Burns (1978) most frequently used the term transforming leadership, he also used the words transformation and transformational. However, the term transformative, often associated with his work, is markedly absent. Nevertheless, the implications of his conception of transformation point directly to transformative leadership, which I will briefly account for in the following.

Burns (1978:202) stated that "revolution is a complete and pervasive transformation of an entire social system" and later he emphasized the need for "real change - that is, a transformation to the marked degree in the attitudes, norms, institutions, and behaviors that structure our daily lives" (ibid:414). Statements such as these clearly indicate that transformational leadership does not adequately exemplify his understanding of transforming leadership-leadership that explicitly attends to the moral and ethical issues related to power relationships of entire social systems that often perpetuate inequity and inequality in organizations. Transformative approaches to leadership have been quite common in health care and related (e.g: Watkins 2000, Duncan, Alperstein, Mayers \& Olckers 2006, Evans, Hanlin \& Prilleltensky 2007) social service research. Nevertheless, more recently transformative concepts of leadership have also been used as a theoretical framework in educational research (e.g: Brown 2004, Dantley \& Tillman 2010, Shields 2011). I have used a transformative approach to investigate what expectations are assigned to school leadership regarding knowledge, skills and attitudes.

The notion of transformation has led, in education, to concepts such as transformative teaching, the transformative classroom (Duncan \& Clayburn 1997), transformative curriculum, transformative material activity (Miettinen 2006) and so forth. Furthermore, whereas transformational leadership accepts the context and parameters within which schools work and predetermined organizational objectives are given, transformative leadership seeks also to change the context to better suit the needs of the students and community and thus takes school contexts seriously (Thrupp \& Lupton 2006). Hence, an important distinction between transformational and transformative leadership is that the former focuses on the capacity to develop infrastructure, and as Leithwood and colleagues (Leithwood, Harris \& Hopkins 2008) have framed it, it is about setting direction, developing people, and redesigning the organization. Thus, the focus is primarily on what happens within the organization. Transformative leadership, on the other hand, focuses more on sociological and cultural elements of the organization and the wider society in which they are embedded. It gives particular emphasis to the need to recognize that the inequities experienced in the wider society affect one's ability to perform and to succeed within the school.

Shields (2010) identifies seven key developments of transformative leadership: a combination of acknowledging power and privilege, articulating both individual and collective purposes, deconstructing social-cultural knowledge frameworks that generate inequity and reconstructing them, balancing critique and promise, effecting deep and equitable changes, working towards transformation, liberation, emancipation, democracy, equity and justice, and demonstrating moral courage and activism. Her delineation of transformative leadership theory is based on the following:

Notions of promise, liberation, hope, empowerment, activism, risk, social justice, courage, or revolution do not automatically evoke images of educational leaders in charge of schools and systems, working within the dominant political and bureaucratic frameworks of the 21 st century. Yet, all of these concepts are at the heart of transformative leadership (Shields 2010:559).

Through the lenses of transformative leadership, the study analyzes what expectations are assigned to school leadership through education policy documents pertaining to a multicultural society with regard to knowledge, skills and attitudes. I assume that the lenses provide my research with a potential to understanding what recommendations are promoted to the critically important role of school leaders in preparing schools to teach all students to become caring, engaged global citizens.

\section{The White Papers}

The ministries publish several types of documents. This study draws on seven White Papers. These are reports written by bureaucrats in the ministries, formulated as objectives. They are not related to legislation as such. Although White Papers do not have the same status as government prescriptions expressed in laws, regulations pursuant to the school law and circulars (Pihl 2001), they usually provide a foundation for future legislation. Likewise the White Papers present several government initiatives that often will result in increased costs, for both the central and the local government. The Government may return to the realization of the measures, the introduction pace and scope of the annual budget proposal, for example regarding school development or in service training. Given their status as documents with the purpose to give recommendations and promote an overall and integrated future policy in a field, 
White Papers are texts that serve as reference points for the government discourse (Neumann 2001). This study investigates the government discourse about school leadership and ethnic and linguistic diversity, i.e. what characterizes government rhetoric in relation to what tasks are assigned to school leadership with regard to knowledge, skills and attitudes. Since the latest school reform in 2006, the Knowledge Department has produced 22 White Papers, including White Paper 30, which is one of the most central documents prior to the reform. The White Papers selected for this study both build on and is delineated on the basis of previous reports in the current period. For example White Paper 19 (Norwegian Ministry of Education and Research 2010) introduced measures to promote better use of teachers' time, among other measures intended to improve school leadership. Likewise, White Paper 18 jointly promoted measures to improve the education system's ability to intercept and monitor students who need special help and support in education. White Paper 6 (Norwegian Ministry of children, equality and social inclusion 2012) notified principles that should form the basis for all work in day care and education sectors, and in order to safeguard the principles of diversity and multilingualism, democracy and tolerance, early intervention, long-term language training and fostering of multicultural perspectives in universal measures, the government will implement competence in the multicultural area for primary and secondary education, to mention the most relevant areas for the investigation of school leader competences and expectations towards the school leader role and school leadership practice. The 7 documents chosen for this study have moved the discourse about ethnic and linguistic diversity back and forth. As such, policy documents can be understood as the result of ongoing political negotiations. They may also serve as important school policy indicators.

\section{A Thematic Approach to Document Analysis}

The study aims to investigate what expectations are assigned to school leadership through education policy documents pertaining to a linguistically and ethnically diverse society, and data from seven Reports to the Storting (White Papers) are thematically analyzed. Thematic approaches are appropriate for this study as they are concerned with analyzing, and making sense of, a set of field notes or transcripts from interviews, or free-flowing texts from secondary data sources, such as in document analysis (Braun \& Clarke 2006). I investigate the government's ideas expressed as objectives in the documents. A thematic analysis provides me with a tool to move beyond counting explicit words or phrases and to focus on identifying and describing implicit and explicit ideas with the data, that is, themes. I am specifically investigating three themes; knowledge, skills and attitudes. The thematic analysis I apply for this study borrows from several theoretical and methodological camps. For example, it shares many features with grounded theory (Glaser \& Strauss 1967, Charmaz 2006, Corbin \& Strauss 2008), and phenomenology (Moustakas 1994, Giorgi 2009, Smith, Flowers \& Larkins 2009). At the same time there are several differences. For example, although grounded theory, by definition, aims at building theory, thematic analysis is not restricted to this purpose. In like manner, interpretative phenomenology is preoccupied with subjective human experience, whereas thematic analysis is often broader and includes social and cultural phenomena such as, in this study, school leadership and linguistic and ethnic diversity. Thus, I consider a pragmatic approach focusing on using whatever tools might be appropriate as strength to get the analytic job done in a transparent and ethical manner. Still, using a thematic analysis approach I acknowledge the risk that my own perspectives and pre-understanding may affect the selection of texts and the interpretation (Grønmo 2004). However, having concepts from two contrasting leadership approaches will reduce this challenge. Equally important, I have discussed critical and other contextual considerations. One crucial task is to consider the documents' relevance concerning the study's main question. Through the discussion of relevance the consideration of the authenticity and trust may be strengthened as well. Examining seven White Papers published between 2003 and 2013 and having a glance at the content list made it possible to have an idea of which could be relevant to search for information about school leadership. I was particularly searching for the word leadership and linguistic and ethnic diversity. Looking for themes, ie. knowledge, skills and attitudes, in the documents involved pawing through texts and marking them.

Using the analysis software program HyperREASEARCH, I looked for and marked what may refer to what a school leader is expected to know about, and understand, what he/she is expected to do and master, and what he/she is expected to stand for, identify with, commit to, and signal. Moreover, research has long recognized that much can be learned from qualitative data by what is missing data. Bogdan and Taylor (1975) suggested being "alert to topics that your subjects either intentionally or unintentionally avoid" (Ibid:82). Hence, I also concentrated on what is not included in the texts, i.e what could relate to expectations regarding knowledge, skills and attitudes which may not be identified within a transformative leadership approach. Some of the seven documents became more relevant than others. At the same time, as referred to above, from a methodological point of departure, some of the documents' lack of reference to the themes also caught my interest.

Analyzing the documents I used a theoretical approach as the analysis was driven by my specific interest in school leadership and linguistic and ethnic diversity. The themes were then coded in terms of knowledge, skills, and attitudes, hence the data merged into already identified themes. I analyzed the documents for representations of what may be expected from school leaders with regard to these aims, which are crucial to school renewal efforts, and consistent with 
the school's mandate. The White Papers that are analyzed in this article, except for White Paper 30 (Norwegian Ministry of Education and Research 2004), which was published after the introduction of the Knowledge Promotion Reform, introduced in autumn 2006. The papers were chosen because they express the most important issues of the government's policy regarding developing an educational policy for the current decade. They all serve to inform the study of different aspects of what may be expected from school leaders. Some of them are more specific and have extended discussions about expectations (e.g. White Paper 31). Others (e.g. White Paper 44) only have brief discussions about school leadership, and often refer to forthcoming White Papers, or even already published White Papers. I outline an overview of the documents in table 2 below, and briefly outline an overview of my choice of the papers with regard to status and relevance.

Table 2. Overview of the White Papers

\begin{tabular}{|c|c|c|c|}
\hline Policy document & Title & Purpose & Published by \\
\hline $\begin{array}{l}\text { Report to the Storting } \\
\text { no } 30 \text { (2003-2004) }\end{array}$ & Culture for learning & $\begin{array}{l}\text { Promotes a series of proposals that are supposed to help schools to be } \\
\text { able to meet the challenges they face. }\end{array}$ & $\begin{array}{l}\text { Ministry of } \\
\text { Education and } \\
\text { Research }\end{array}$ \\
\hline $\begin{array}{l}\text { Report to the Storting } \\
\text { no } 16 \text { (2006-2007) }\end{array}$ & $\begin{array}{l}\text {...and no one was left } \\
\text { behind. Early intervention } \\
\text { for life long learning }\end{array}$ & $\begin{array}{l}\text { Aims at providing many answers to how we can be more successful to } \\
\text { assist each individual to develop and realize their life projects, and it } \\
\text { indicates direction of the effort that must be done. }\end{array}$ & $\begin{array}{l}\text { Ministry of } \\
\text { Education and } \\
\text { Research }\end{array}$ \\
\hline $\begin{array}{l}\text { Report to the Storting } \\
\text { no } 31 \text { (2007-2008) }\end{array}$ & Quality in schools & $\begin{array}{l}\text { Presents the quality goals for the primary and secondary education } \\
\text { and training and measures to increase the benefit the pupils derive } \\
\text { from the tuition. }\end{array}$ & $\begin{array}{l}\text { Ministry of } \\
\text { Education and } \\
\text { Research }\end{array}$ \\
\hline $\begin{array}{l}\text { Report to the Storting } \\
\text { no } 44 \text { (2008-2009) }\end{array}$ & Education strategy & $\begin{array}{l}\text { Carries out analyses and action by White Paper } 16 \text { (Norwegian } \\
\text { Ministry of Education and Research 2006) and White Paper } 31 \\
\text { (Norwegian Ministry of Education and Research 2007) }\end{array}$ & $\begin{array}{l}\text { Ministry of } \\
\text { Education and } \\
\text { Research }\end{array}$ \\
\hline $\begin{array}{l}\text { Report to the Storting } \\
\text { no } 19 \text { (2009-2010) }\end{array}$ & Time for learning & $\begin{array}{l}\text { Outlines for monitoring the time spent, recommendations and } \\
\text { promotions of initiatives that can contribute to a more efficient use of } \\
\text { teachers' time. Likewise there are a number of recommendations also } \\
\text { for school owners and school leaders. }\end{array}$ & $\begin{array}{l}\text { Ministry of } \\
\text { Education and } \\
\text { Research }\end{array}$ \\
\hline $\begin{array}{l}\text { Report to the Storting } \\
\text { no } 18 \text { (2010-2011) }\end{array}$ & $\begin{array}{l}\text { Learning together. Early } \\
\text { intervention and good } \\
\text { learning environment for } \\
\text { children, youths and } \\
\text { adults with special needs. }\end{array}$ & $\begin{array}{l}\text { The target group for White Paper } 18 \text { (Norwegian Ministry of } \\
\text { Education and Research 2010) is children, young people and adults } \\
\text { in need of special educational assistance and support. At all levels of } \\
\text { the education system there are children, young people and adults } \\
\text { who suffer from mobility impairments, visual impairments, hearing } \\
\text { impairments and physical disabilities, significant language, speaking } \\
\text { and communication difficulties, as well as brain injuries. }\end{array}$ & $\begin{array}{l}\text { Ministry of } \\
\text { Education and } \\
\text { Research }\end{array}$ \\
\hline $\begin{array}{l}\text { Report to the Storting } \\
\text { no } 6 \text { (2012-2013) }\end{array}$ & $\begin{array}{l}\text { A coherent integration } \\
\text { policy. } \\
\text { Diversity and community }\end{array}$ & $\begin{array}{l}\text { Provides a comprehensive presentation of Government's integration } \\
\text { policy. }\end{array}$ & $\begin{array}{l}\text { Ministry of } \\
\text { Children, } \\
\text { Equality and } \\
\text { Social Inclusion }\end{array}$ \\
\hline
\end{tabular}

Next I present several interesting findings, and conclude with an analysis of the research questions in light of these observations.

\section{Expectations Assigned To School Leadership with Regard to Knowledge}

White Paper 30 (Norwegian Ministry of Education and Research 2004) emphasizes that one success criterion for adapting to a knowledge-intensive and diverse society is that it requires school leaders with the knowledge to meet a more ethnically and linguistically diverse student and parents group. Second, school leaders also need the knowledge of the strengths and weaknesses of their own school. Third, it requires school leaders who have the knowledge about leading the development of a culture for continuous learning. Leadership within a multicultural school context implies knowledge about how power and privilege in the wider society affect one's ability to perform and to succeed within the school. Likewise, the paper emphasizes that proper and adequate competence is a prerequisite for quality in schools, and for all other measures to succeed. For example, with regard to measures to increase the recruitment of people with immigrant backgrounds to secondary and higher education, the document refers to the Government's aim to give minority language students, with incomplete secondary education, training with peer majority language youth as soon as possible. White Paper 19 (Norwegian Ministry of Education and Research 2010) emphasizes that fundamental to all leadership in schools is knowledge of the school as an organization, its social mandate, student rights and conditions for learning and 
development. Such insight provides the basis for educational decisions at all levels, from planning to implementation. This may relate to a transformational leadership approach, focusing on improving organizational qualities, rather than challenging inappropriate use of power that creates or perpetuates inequity and injustice (Shields 2010) in a multicultural school context. It is also shown how the professionalization of leadership work in schools should be part of ongoing, systematic work, from basic education of leaders of schools and throughout their career. White Paper 6 (Norwegian Ministry of children, equality and social inclusion 2012) emphasizes the need to strengthen the school leaders' expertise in multicultural education, multilingual development, adult education and second language education. Knowledge of language stimulation, mapping of language skills, organization and content of different types of knowledge of good practice should also be strengthened. Furthermore, the paper acknowledges that school leaders and school owners are facing very different challenges in different parts of the country, as the proportion of students varies from municipalities to municipalities. In turn this may provide different kinds of challenges concerning the organization of the training. In some municipalities and counties there are expertise and experience to provide good training for minority students, while others have little experience and lack of expertise.

In sum, the documents share the focus on the need for school leaders to increase their knowledge about the schools' organizational elements. For example, although White Paper 30 (Norwegian Ministry of Education and Research 2004) points to the need for school leaders to adapt to a diverse society, the knowledge with regard to the school's organizational features is underscored. White Paper 19 (Norwegian Ministry of Education and Research 2010) pays attention to students' rights and conditions for learning, while school leaders' knowledge about minority students, or challenges with linguistic and ethnic diversity, are not explicitly connected to what is mentioned as professional leadership. Here again, like White Paper 30 (Norwegian Ministry of Education and Research 2004), the primary focus is on knowledge about the school as an organization and its overall general mandate with regard to learning and development. Hence, the documents' emphasis indicates an overall focus on a transformational leadership approach, such as knowledge with regard to developing common purpose, and focusing on organizational goals and smooth running of the school. The analysis displays few indications of a transformative approach to leadership, for example by emphasizing social or cultural knowledge frameworks that generate inequity, acknowledgement of power, and privilege.

In the other papers I did not identify texts related to school leaders' knowledge regarding linguistic and ethnic diversity. Nevertheless, concerning school leaders' skills, I identified relevant texts in almost all policy documents explored.

\section{Expectations Assigned to School Leadership with Regard to Skills}

Within a transformative approach to school leadership expectations with regard to skills imply for example deconstruction of social-cultural knowledge frameworks that may generate inequity, and effecting deep and equitable changes. Identifying school leadership skills, i.e. what a school leader ought to do and be able to master, White Paper 30 (Norwegian Ministry of Education and Research 2004) is preoccupied with tasks of strengthening the teachers' pedagogical competence and motivates for improvements and change. Likewise, school leaders are proposed to cooperate with flexibility and variety. Additionally, school leaders ought to demand and stimulate for learning. This may refer to a transformational approach which emphasizes the need for school leaders to inspire and develop the school, and managing the instructional program. White Paper 16 (Norwegian Ministry of Education and Research 2006) is preoccupied with ensuring high expectations, both with regard to supportive learning and avoiding social reproduction, thus skills regarding developing a ground for the students' completion of upper secondary school. Moreover, school leaders are expected to maintain concentration and focus on the students' competence aims. Competence aims are given in key curricula, and express what is important knowledge and skills in the various school subjects. School leaders are also supposed to follow up efforts to ensure improved competence, and adapted teaching for each individual student. School leaders' skills with regard to documentation of students' learning outcomes, is also emphasized as a means for a better co-operative climate which in turn will benefit the students' learning results. Here again the focus is predominantly on a need for a smooth running of the school and effective managing of the instructional program.

In like manner, what may be identified through the lenses of a transformational approach, rather than a transformative approach, several skills in relation to leadership are identified in White Paper 31 (Norwegian Ministry of Education and Research 2008); Improved utilization of learning in daily life, strengthening of the collective learning culture in schools, setting goals, motivate, evaluate, prioritize activities, and decision-making that improves learning outcomes. Furthermore, it is also expected that school leaders have the capacity to develop a culture for co-determination for teachers, avoid "laizzes faire", i.e. are "hands-on", and facilitate skills development in the organization. Also school leaders ought to do administrative work, such as managing financial resources. Explicitly mentioned is motivating and mentoring teachers.

In White Paper 18 (Norwegian Ministry of Education and Research 2011) a common thread is early intervention and skills in school. The document emphasizes high school leader capacity as a key assumption for social cohesion, and school leaders' contribution in establishing good systems for assessment and feedback and variation in training. Also it is 
displayed that newly appointed principals will be offered school leadership training. This point is the first explicit expression in the documents regarding formal studies for school leadership. The competence building vision expressed in report 30 shows what may be offered to school leaders. Likewise, school leaders are supposed to build teams around the teachers, and be supportive with regard to various special education fields. Successful school leadership is referred to as taking responsibility for student learning outcomes and learning environment. This requires expertise in leading, teamwork and organizational development. Furthermore, guidance of teachers, development and change are central to any leader. School leadership is also characterized by good communication, emphasis on building relationships in the organization and an awareness of how conditions can be made for teachers' work. Moreover, it is expected that school leaders have skills which enable them to build schools for learning organizations by being updated and update, promote and share the responsibilities and duties, be experimental and take risks - all the time with the students' learning and results in focus. Risk-taking is the first explicit expectation which may relate to a transformative approach. Furthermore, to meet a knowledge-driven linguistically and ethnically diverse society, schools require competent school leaders with positive attitudes to change in order to develop into a learning organization. Moreover, they are expected to take the time to talk with teachers, students and the community outside the school. In White Paper 19 (Norwegian Ministry of Education and Research 2010) the emphasis is on joint efforts, effective use of time for the benefit of students' learning, and the need for school leaders to pave the way for teachers to grow. Here too school leaders are supposed to create a climate for taking risks and being explorative.

As noted above, White Paper 16 (Norwegian Ministry of Education and Research 2006) identifies school leaders' commitment to participate in skills development strategy. Similarly, White Paper 31 (Norwegian Ministry of Education and Research 2008) additionally emphasizes that clearer responsibilities and local agency imposes new demands on school leaders. It points to the need of principals who are skilled educational and organizational leaders, and who through the leadership of the school's development must help improve pupils' learning outcomes. Moreover, it is emphasized that many schools have too weak supportive leadership and insufficient capacity to conduct professional development and monitor school improvement in a good way.

White Paper 44 (Norwegian Ministry of Education and Research 2009) emphasizes that national centers will offer guidance and support to the educational practice in a number of disciplines. Hence it is expected that school leaders take inspiration to put the spotlight on good methodology and provide inspiration to vary and adapt training to various students and student groups. Moreover, school leaders are expected to have the capacity and expertise to analyze, interpret and make decisions based on information on education and student performance. White Paper 6 ( Norwegian Ministry of children, equality and social inclusion 2012) states that there is a need to strengthen the skills of teachers, school leaders and school owners in elementary and secondary education. There is among other things a need for expertise in multicultural education, multilingual development, adult education and second language education. Knowledge of stimulation, mapping of language skills, organization and content of the different types of offers and knowledge of good practice should also be strengthened. Neither of the other documents from the Knowledge department that I investigated included such explicit expressions of what is needed for school leaders in a multicultural school. Still, there is no voice with regard to inequity and reconstruction of social-cultural knowledge frameworks, or effecting deep and equitable change, as identified within a transformative approach.

In sum, White Paper 30 explicitly emphasizes a demand for school leaders to have relevant skills to meet a diverse student and parents group. White Paper 31 is more implicit, acknowledging that an increased complexity requires increased demands of pedagogic competence and necessary leadership capacity. The papers refer to competence about leadership and as being decisive. They emphasize skills with regard to organizational aspects as a prerequisite for good learning conditions, both for students and teachers. The papers also explicitly outlined the skills regarding building a collective learning culture in the organization through inspiration and motivation. The documents point at the national school leader education program as a means to develop these skills. White Paper 6 is explicitly arguing for a specific focus on competence development with regard to multicultural education in school leadership preparation programs. Neither of the other documents explicitly addresses linguistic and ethnic diversity when referring to the national school leader program. An overall focus is on the organizational elements, and more specificially on the school leaders' skills with regard to having the capacity to inspire, motivate and initiate team building in order to develop a shared common purpose. There is an emphasis on dimensions related to a transformational approach to leadership. However, the explicit expectation in two of the papers regarding developing a risk taking climate and avoiding social reproduction, may relate to a transformative school leadership approach.

\section{Expectations Assigned to School Leadership with Regard to Attitudes}

Expectations assigned to school leadership with regard to attitudes within a transformative approach relate to liberation, emancipation, democracy, equity and justice, and demonstrating moral courage and activism. However, with regard to what a school leader is expected to stand for, identify with, commit to, and signal, several documents emphasize 
commitment, consciousness, engagement, improvement, and responsibility. These attitudes relate to a transformational approach rather than a transformative approach. For example, White Paper 30 (Norwegian Ministry of Education and Research 2004) emphasizes that all plans to develop and improve the school will fail without school leaders who are committed and ambitious about developing learning organizations. Learning organizations place particular demands on consciousness regarding school knowledge goals. School leaders are also supposed to ask for and encourage learning in everyday work, be conscious and reflect on learning strategies, to do networking and teamwork. The paper claims that school leaders are reluctant to engage in dialogue about how to improve. Hence it states, there is a need to make significant efforts to increase the capacity of school leaders, both academically and didactically. This is further developed and emphasized in White Paper 16 (Norwegian Ministry of Education and Research 2006), which refers to the importance for school leaders to participate in skills development strategy programs. White Paper 31 (Norwegian Ministry of Education and Research 2008) underscores that there has been a significant investment in development for school leaders in order to support the introduction of the Knowledge Promotion. Principals and school leaders are supposed to play an important role for students' learning outcomes. Furthermore, clearer responsibilities and local agency impose new demands on school leaders. Hence it is stressed that there is a need for school leaders who can execute leadership which contributes to improving student learning. School leaders are supposed to receive support from the school owner. Likewise they are also supposed to be willing to read academic literature about school and leadership. As already noted, the principal and the school leadership team have impact on both student learning and well-being in several ways. First and foremost, by having the responsibility to set common goals and inspire joint efforts to achieve the objectives and monitor whether the objectives have been achieved. Also it is expected that they prioritize available resources in the best possible way. The report explicitly emphasizes that school leaders are obliged to take part in a 30 credits school leadership education program, which is part of a more comprehensive master's degree in school leadership.

Furthermore, White Paper 44 (Norwegian Ministry of Education and Research 2009) emphasizes the school leaders' academic responsibility for the pedagogic work. Likewise, they ought to take inspiration and coaching from the national centers regarding methods and adapted education for the variety of student groups. It also points to the school leaders' responsibility to develop methodologically and didactically. In White Paper 18 (Norwegian Ministry of Education and Research 2011) it is emphasized that all newly appointed head teachers as well as heads with no previous education in leadership will be given the opportunity of taking further education in a school leadership program.

To summarize, a main focus within all the documents pertaining to attitudes explored and reported here, is on organizational efforts, and the expectations that school leaders take part in competence building programs, and meet the needs of a linguistically and ethnically diverse society. There are no references to expectations assigned to school leadership with regard to attitudes within a transformative approach, such as liberation, emancipation, justice, and demonstrating moral courage and activism.

In the following I will first discuss the results through lenses of dimensions basic to transformative leadership (acknowledging power and privilege, articulating purpose). Finally I will briefly address some tentative conclusions and possible implications for school leadership in a linguistically and ethnically diverse school context.

Undoubtedly, transformative leadership is to some extent a normative approach. Hence, the following discussion must be seen in the light of this acknowledgement.

\section{Discussion}

The aim of this study is to investigate what expectations are assigned to school leadership through education policy documents pertaining to a multicultural society with regard to knowledge, skills and attitudes. There are few indications of knowledge, skills and attitudes pertaining to a multicultural school which may relate to a transformative approach. The policy documents reflect what has already been indicated initially, in Norway, as in several other countries throughout the globe; in the last decade there have been increasing concerns about the quality of schooling. There is a continuous development towards a stronger focus on educational quality, in terms of students' achievements and more output-oriented means of governing. Hence, the emphasis is on more or less well-defined expectations of what has to be achieved and by whom, and only those outcomes that meet the predefined criteria are considered successful. In a multicultural school where the student body consist of a diverse group of students with different linguistic and ethnic backgrounds this may foster less equity education.

There are indications of inspiration from New Public Management (NPM) strategies in the documents, which may be motivated by concerns about reducing disparities in learning outcomes across different social groups, thus strengthening the state's role in monitoring schools (Røvik 2007). Notwithstanding, it is also argued that the cost of the public sector is too high, and that NPM strategies work as instruments for efficient service production, governed by a performance oriented culture with a focus on results and efficiency (Olsen 2006, Heinrich 2007). Consequently, except for a few examples like "risk taking" and "social justice", there is little evidence of expectations assigned to school leadership 
and multicultural schools which explicitly relate to transformative leadership. There seems to be a lack of a transformative movement that may enhance leadership practice deriving from critically thinking socially active school leaders and teachers. Hence, there is little evidence of explicit knowledge, skills and attitudes, and a new dedication to laying the foundation for the transformation of society.

Objectives formulated by the government through White Papers are potentially powerful acts of democracy. The White Papers analyzed in this study provided no clear indications of addressing the reality that some groups in school are advantaged and included in the daily operations and decisions of the school, and that other groups may be generally excluded, disadvantaged, and often marginalized. Burns' (1978) concept of power as a relationship provides a view to understand that power must be taken seriously. For him, power is first of all a relationship, collective, and not simply the conduct of one person. Hence, power and privilege as organizational qualities must be nurtured, developed, and understood as a way of moving towards a collective purpose.

The articulation of purpose of schooling, as referred to in the reports was not explicitly connected to power and privilege, or equity. Here it may be possible to identify a critical difference between transformational and transformative leadership. As desirable as strategies within the former are for attaining an organizational goal, it is essential that the goals and purposes of the education endeavor be made explicit (Shields 2011). Within a transformative leadership approach it is crucial to emphasize issues like deep democracy (Green 1999), racism (Dei 1996), social class (Bernstein 1960), and deficit thinking (Valencia 1997, Shields, Bishop \& Mazawi 2005), and to explore how such issues may create a learning culture that may privilege some and disadvantage linguistically and ethnically minority students. Moreover, articulating the purpose of schooling goes beyond contribution as a member of society regarding economic matters. Rather, it ought to be accompanied by a clear understanding of social, cultural, and political participation as a global citizen (Banks 2008). There is a need for explicitly articulating the purpose of education, and that the goals and purposes of the educational endeavor are made explicit. Within a transformative point of view that would imply the importance of the goal to be one of transformation, equity, and substantial social change. Thus it is necessary to articulate and attain purposes in terms of mutual benefit and social change. Emphasizing this, Astin and Astin (2000), for example assert that the value ends of leadership should be to enrich equity, social justice, and the quality of life. Moreover, leadership ought to contribute to expand access and encourage respect for diversity. In sum, they point at strengthening democracy.

The analysis displayed few indications of expectations related to a transformative approach to leadership, for example by emphasizing a need for new knowledge frameworks. Within a transformative leadership approach, in order to further develop and challenge the ways in which we think about schooling, it is important for school leaders to engage in conversations about how to deconstruct social-cultural knowledge frameworks that generate inequity and reconstructing them. For example, by deconstructing inappropriate attitudes and assumptions and common wisdom that has been passed on for years (Shields 2011). Likewise, one of the primary tasks of a transformative leader (Shields 2003, 2010,2011 ) is to challenge how implicit cultural assumptions, frames of reference, perspectives, and biases influence how knowledge is constructed (Berger \& Luckmann 1991).

In order to deconstruct existing inappropriate knowledge frameworks, critique and promise become crucial first steps for school leaders. First, it is important to recognize, for example how standards and high stakes accountability tied to student performance on standardized tests have effects on linguistic and ethnic minority students. To exemplify, Hvistendahl and Roe (Hvistendahl and Roe 2004, Hvistendahl and Roe 2009) in their study present the literacy achievement of minority students, their reading habits, and their enjoyment of reading based on the Program for International Student Assessment (PISA) study. Results indicate that aspects of their family background and attitudes towards school are related to literacy achievement results. This shows that schools in Norway not only face the challenge of educating minority students with a different first language, but also the challenge of equalizing the effects of socio-economic status for minority students in general, and even a challenge to realization of the educational mandate (Pihl 2011).

Second, what is to be expected from a transformative leader may be in accordance with what Greene (1988) asserts; the promise that education is able to prepare students to be "citizens of the free world, having the capacity to choose, the power to act to attain one's purpose, and the ability to help transform a world lived in common with others" (ibid:32). Without ensuring that students have learned basic skills, this is a goal which includes the need to recognize and address the inequities both in the local school and around the world and to learn to live and act in such a way as to make a difference in achieving deep and equitable change (Shields 2011). One prerequisite for deep and equitable change may be to identify the specific changes needed in the school leaders' own context in order to achieve the goals of equity and social justice.

Expectations with regard to spending time building a collective learning culture in the organization through inspiration 
and motivation, as noted in most of the reports, may satisfy an accountability mandate. However, it does not guarantee that the work will focus on the broader citizenship goals of education. I did not identify references to expectations assigned to school leadership with regard to attitudes within a transformative approach, such as liberation, emancipation, and equity. The questions at the heart of transformative leadership relate to how educators can create learning environments that empower all students, how race, class, ability, or disability affect a student's ability to learn, who is marginalized, excluded, or disadvantaged by a given decision, and who is included and privileged. Recognizing these questions requires school leaders who are expected to "confront more than just what is, and work toward reacting and alternate political and social imagination that does not rest solely on the rule of capital or the hollow moralism of neo conservatism, but is rooted in radical democratic struggle" (Weiner 2003:97). The reference in some of the documents regarding expectations to take risk may demonstrate reference to demonstrating moral courage and activism.

From a transformative approach this implies leaders who are able and willing to confront privilege and advocate for learning from the perspectives and values of linguistic and ethnic minority students, and reach beyond a fear of authority (Agans \& Korach 2012).

Results showed few indications of a transformative approach to leadership. Nevertheless, I have underscored what may be important expectations regarding school leaders' knowledge, skills, and attitudes. A transformative approach to leadership may serve what political theorist Barber (2001:12) states: "the fundamental task of education in a democracy is the apprenticeship of liberty - learning to be free", and to "protect and support the inner journey that is at the heart of authentic teaching, learning, and living" (Palmer 2007:ix). The potential of school leaders to be crucial contributors for education to transform society must not be underemphasized. There are several challenges regarding what may be expected from a transformative approach discussed above, for example emphasis on high-stake testing, narrow forms of accountability, and performativity.

The analysis and discussion have exposed that schools with predefined criteria, and NPM strategies may foster less equity education for minority students. Consequently, there is a need to strengthen the focus on how school leaders can contribute to play a more critical role in developing schools as laying the foundation for transforming of society. Thus, deriving from this study, in the concluding remarks, I address possible implications for school leadership preparation programs.

\section{Concluding Remarks}

Designing a school leadership preparation program for the $21^{\text {st }}$ century, I suggest the following dimensions of multicultural education (Banks 2006b) in order to develop school leaders' knowledge, skills, and attitudes. First, school leaders need to address school development initiatives which ensure that teachers use examples and content from a variety of cultures and groups to illustrate key concepts. Second, they need to contribute to ensuring equity pedagogy, i.e. a modification of teaching in ways that will facilitate the academic achievement of linguistic minority students. Third, there may be a need to developing an empowering school culture, i.e. the process of restructuring the culture and organization of the school so that minority students may experience educational quality and cultural empowerment. Fourth, focusing on the characteristics of student's racial attitudes and how they can be modified by teaching methods and materials. Fifth, how teachers may help students to understand, investigate, and determine how implicit cultural assumptions, frames of reference, perspectives, and biases within a discipline influence the ways in which knowledge is developed. Focusing on these dimensions in a school leadership preparation program may help school leaders develop a school which is aware of and able to distinguish between four approaches to a multicultural curriculum reform (Banks 2006a). The contribution approach is often the most frequently used. It is characterized by focusing on heroes, holidays, and discrete cultural elements. The additive approach emphasizes that content, concepts, themes, and perspectives are added to the curriculum without changing its structure. The transformation approach goes on to change the structure of the curriculum to students to view concepts, issues, events, and themes from the perspectives of linguistic minority students. The social action approach aims at ensuring that linguistic minority students and their parents make decisions on important social issues and taking actions to help solve them. Through a multicultural education focus in a school leadership program, the school leaders develop knowledge, skills and attitudes to view the four approaches for the integration of multicultural content in the curriculum as mixed and blended in actual teaching situations. This implies for example, acknowledging that the move from content integration to the social action approach is likely to be gradual and cumulative. In sum, there is a need to ensure leadership preparation programs that are in touch with reality, i.e. a reality that is diverse in many ways, including a linguistic and ethnic diversity. 


\section{References}

Agans, L., \& Korach, S. (2012). Transformative school leadership. In Gerstl-Pepin, C \& Aiken, J. (Eds.), Social Justice Leadership for a Global World. Vermont: Information Age Publishing Inc.

Andersen, F.C., \& Ottesen, E. (2011). School leadership and ethnic diversity: approaching the challenges. Intercultural Education 22(4), 285-300. http://dx.doi.org/10.1080/14675986.2011.617422

Anderson, G. L. (2009). Advocacy leadership: Toward a post-reform agenda in education. New York: Routledge.

Astin, A., \& Astin, H. (2000). Leadership reconsideres: Engaging higher education in socail change. Battle Creek, MI: WK Kellog Foundation.

Bakken, A. (2009). Ulikhet på tvers. Har foreldrenes kjønn, utdanning og minoritetsstatus like stor betydning for elevers karakterer på alle skoler? Oslo: Norsk institutt for forskning om oppvekst, velferd og aldring.

Banks, J. (2006a). Approaches to multicultural curriculum reform. In Banks, J. (Ed), Race, Culture and Education. The selected works of James A. Banks (p. 140-144). London and New York: Routledge.

Banks, J. (2006b). Democracy, diversity, and social juctice: educating citizens in a global age. In Banks J. (Ed), Race, Culture, and Education. The selected works of James A. Banks (p. 199-213). New York: Routledge.

Banks, J. (2008). Diversity, Group Identity, and Citizenship Eucation in a Global Age. Educational Researcher 37(3), 129-139. http://dx.doi.org/10.3102/0013189X08317501

Barber, B. (2001). An aristocracy of everyone. In Goodlad, S.J. (Ed), The last best hope: A democracy reader (p. 11-22). San Francisco, CA: JosseyBass.

Bass, B., \& Aviolo, B. (1994). Improving organizational effectiveness through transformational leadership. Thousand Oaks, CA: Sage Publications.

Bass, B., \& Riggio, R. (2006). Transformational leadership. Mahwah, NJ: Lawrence Erlbaum.

Berger, P. L., \& Luckmann, T. (1991). The social construction of reality: A treatise in the sociology of knowledge. Harmondsworth: Penguin.

Bernstein, B. (1960). Language and social class. The British Journal of Sociology 11(3), 271-276.

Blackmore, J., \& Sachs. (2007). Performing and reforming leaders: Gender, educational restructuring organizational change. New York, NY: SUNY.

Bogdan, R., \& Taylor, S.J. (1975). Introduction to qualitative methods. New York: Wiley.

Braun, V., \& Clarke, V. (2006). Using thematic analysis in psychology. Qualitative Research in Psychology 3, 77-101. http://dx.doi.org/10.1191/1478088706qp063oa

Brooks, J., \& Arnold, N. (2013). Toward Equity in Education for America's Students. Charlotte, NC: Information Age Publishing, Inc.

Brown, K. M. (2004). Leadership for social justice and equity: Weaving a transformative framework and pedagogy. Educational Administration Quarterly 40(1), 77-108. http://dx.doi.org/ 10.1177/0013161X03259147

Burbules, N., \& Berk, R. (1999). Critical Thinking and Critical Pedagogy: Relations, Differences, and Limits. In Popkewitz, T \& Fendler, L. (Eds). Critical Theories in Education: Changing Terrains of Knowledge and Politics. (p. 45-66). New York: Routledge.

Burns, J. (1978). Leadership. New york, NY: Harper \& Row.

Charmaz, K. (2006). Constructing Grounded Theory: A Practical Guide Through Qualitative Analysis. London: SAGE Publications Inc.

Corbin, J., \& Strauss, A (2008). Basics of qualitative research: Techniques and procedures for developing grounded theory. London: Sage Publications, Inc.

Dantley, M., \& Tillman , L. (2010). Social justice and moral transformative leadership. In Marshall, C., \& Olivia, M. (Eds). Leadership for social justice. p. 19-34). Boston, MA: Allyn \& Bacon.

Darder, A., Baltodano, M., \& Torres, R.D. (2009). Critical Pedagogy Reader. New York, NY: Routledge.

Dei, G. (1996). Critical perspectives in antiracism: An introduction. Canadian Review of Sociology and Anthropology 33(3): 247-267. http://dx.doi.org/ 10.1111/j.1755-618X.1996.tb02452.x

Duncan, M., Alperstein, M, Mayers, P., Olckers, L., \& Bibss, T. (2006). Not just another multi-professional course! Part 1. Rationale for a transformative curriculum. Medical Teacher 28(1), 59-63. 
Duncan, P. K., \& Clayburn, C. (1997, November). Why Haven't I Heard from You? Evoking the Voices of Adult Learners through Transformative Teaching. Paper presented at the annual meeting of the University Council for Educational Administration, Orlando.

Evans, S. D., Hanlin, C. E., \& Prilleltensky, I. (2007). Blending ameliorative and transformative approaches in human service organizations: A case study. Journal of Community Psychology, 35(3), 329-346. http://dx.doi.org/10.1002/jcop.20151

Giorgi, A. (2009). The descriptive phenomenological method in psychology: a modified Husserlian approach. Pittsburgh, PA: Duquesne University Press.

Giroux, H. (1994). Toward a pedagogy of critical thinking. In Walters, K. (Ed). Re-thinking reason: New perspectives in critical thinking (p. 199-204). Albany: State University of New York Press.

Glaser, B., \& Strauss, A. (1967). The discovery of grounded theory. London: Weidenfeld and Nicholson.

Green, J. M. (1999). Deep democracy:Community, diversity, and transformation. Boston, M: Rowman \& Littlefield.

Greene, M. (1988). The dialectic of freedom. New York, NY: Routledge.

Gronn, P. (2002). Distributed leadership as a unit of analysis. The leadership quarterly 13, 423-451. http://dx.doi.org/10.1016/S1048-9843(02)00120-0

Grønmo, S. (2004). Samfunnsvitenskapelige metoder. Bergen, Bokforlaget.

Haugen, C. R. (2010). Equity and Life-Long Learning: An Analysis of White Paper no. 16 (2006/2007) of Norway. Scandinavian Journal of Educational Research, 54(4), 357-376. http://dx.doi.org/10.1080/00313831.2010.493342

Heinrich, C. J. (2007). Measuring Public Sector Performance and Effectiveness. In Peters, B.G., \& Peters, J.P. (Eds) The Handbook of Public Administration. (p24-35). London: SAGE Publications Limited.

Hvistendahl, R., \& Roe, A. (2004). The literacy achievement of Norwegian minority students. Scandinavian Journal of Educational Research, 48(3), 307-323. http://dx.doi.org/10.1080/00313830410001695754

Hvistendahl, R., \& Roe, A. (2009). Leseprestasjoner, lesevaner og holdninger til lesing blant elever fra språklige minoriteter. Norsk pedagogisk tidsskrift, 4, 250-263.

Kjærnsli, M., \& Olsen, V. (2013). Fortsatt en vei å gå. Norske elevers kompetanse i lesing, matematikk og naturfag $i$ PISA 2012. Oslo: Universitetsforlaget.

Ladson-Billings, G. (1995). Toward a theory of culturally relevant pedagogy. American Educational Research Journal, 32(3), 465-491. http://dx.doi.org/10.3102/00028312032003465

Leithwood, K., \& Jantzi, D. (2005). A review of transformational school leadership research 1996-2005. Leadership and Policy in Schools, 4(3), 177-199.

Leithwood, K., Harris, A., \& Hopkins, D. (2008). Seven strong claims about successful school leadership. School Leadership and Management, 28(1), 27-42.

Marshall, C., \& Olivia, M. (2005). Leadership for social justice: Making revolutions in education. Old Tappan, NJ: Allyn $\&$ Bacon.

McLaren, P. (1995). Critical Pedagogy and Predatory Culture. New York, NY: Routledge.

Miettinen, R. (2006). Epistemology of transformative material activity: John Dewey's pragmatism and cultural-historical activity theory. Journal for the Theory of Social Behaviour, 36(4), 390-408.

Moustakas, C. (1994). Phenomenological Research Methods. Thousand Oaks, CA: SAGE Publications Inc.

Møller, J. (2009a). Approaches to school leadership in Scandinavia. Journal of Educational Administration and History, 4l(2), 165-177.

Møller, J. (2009b). Learning to share: a vision of leadership practice. International Journal of Leadership in Education, 12(3), 253-267. http://dx.doi.org/10.1080/13603120802684530

Neumann, I. B. (2001). Mening, materialitet, makt: En innføring i diskursanalyse. Bergen: Fagbokforlaget.

Norwegian Ministry of Education and Research. (2002). Førsteklasses fra første klasse: forslag tilrammeverk for et nasjonalt kvalitetsvurderingssystem av norsk grunnopplæring. [Official Norwegian

Report. (Proposed framework for a national quality assessment system of Norwegian basic training)]. Retrieved July 2013, from http://www.regjeringen.no/nb/dep/kd/dok/nouer/2002/nou-200210.html?id=145378 
Norwegian Ministry of Education and Research. (2003). I første rekke. Forsterket kvalitet i engrunnopplæring for alle. [Official Norwegian Report. (Improved quality in basic education for all)] Retrieved July 2013, from http://www.regjeringen.no/nb/dep/kd/dok/nouer/2003/nou-200316.html?id=147077

Norwegian Ministry of children, equality and social inclusion. (2012). En helhetlig integreringspolitikk. Mangfold og fellesskap. [Report to the Parliament (White Paper no 6: A coherent integration policy diversity and community)]. Retrieved October 2013, from http://www.regjeringen.no/en/dep/bld/documents/propositions-and-reports/white-papers-/2012-2013/meld-st-6-201 22013.html?id=705945

Norwegian Ministry of Education and Research. (2004). Kultur for læring. [Report to the Parliament (White Paper no. 30): Culture for learning]. Retrieved $\quad$ October 17 from http://www.regjeringen.no/nb/dep/kd/dok/regpubl/stmeld/20032004/stmeld-nr-030-2003-2004.html?id=404433

Norwegian Ministry of Education and Research. (2006a). Læreplanverket for Kunnskapsløftet. Norwegian Ministry of Education and Research. Oslo: Statens forvaltningstjeneste.

Norwegian Ministry of Education and Research. (2006b). Tidlig innsats for livslang læring. [Report to the Parliament (White Paper no. 16): Early intervention for lifelong learning]. Retrieved October 17, 2013 from http://www.regjeringen.no/nb/dep/kd/dok/regpubl/stmeld/2006-2007/stmeld-nr-16-2006-2007-.html?id=441395

Norwegian Ministry of Education and Research (2007). Likeverdig opplæring i praksis! (2007-2009). Strategi for bedre læring og større deltakelse av språklige minoriteter i barnehage, skole og utdanning. Oslo, Statens forvaltningstjeneste.

Norwegian Ministry of Education and Research. (2008). Kvalitet i skolen. [Report to the Parliament (White Paper no. 31): Quality in school]. Retrieved August 3, 2013 from http://www.regjeringen.no/nb/dep/kd/dok/regpubl/stmeld/2007-2008/stmeld-nr-31-2007-2008.html?id=516853

Norwegian Ministry of Education and Research. (2009). Utdanningslinja. [Report to the Parliament (White Paper no. 44): Education strategy]. Retrieved August 3, 2013 from http://www.regjeringen.no/en/dep/kd/Selected-topics/policy-for-lifelong-learning/stortingsmeldingom-utdanningsli nja-2.html?id=578904

Norwegian Ministry of Education and Research. (2010). Tid til læring. [Report to the Parliament (White Paper no. 19): Time for learning]. Retrieved August 2013 from http://www.regjeringen.no/nb/dep/kd/dok/regpubl/stmeld/2009-2010/Meld-St-1920092010.html?id=608020

Norwegian Ministry of Education and Research. (2011). Læring og fellesskap. [Report to the Parliament (White Paper no. 18): Learning together]. Retrieved August 3, 2013 from http://www.regjeringen.no/nb/dep/kd/dok/regpubl/stmeld/2012-2013/meld-st-1820122013.html?id=716040

Nusche, D. (2009). What Works in Migrant Education? A Review of Evidence and Policy Options. OECD Education Department Working Papers 22. Paris: OECD.

OECD (2010). Closing the Gap for Immigrant Students. Policies, Practice and Performance. Paris: OECD Publications.

Olsen, J. P. (2006). Maybe it is time to rediscover bureaucracy. Journal of public administration research and theory, $16(1), 1-24$.

Palmer, P. (2007). The courage to teach. San Francisco, CA: Jossey-Bass/Wiley.

Pihl, J. (2001). Paradoxes of inclusion and exclusion in Norwegian educational reforms in the 1990s. Nordisk tidsskrift for spesialpedagogikk, 1, 14-33.

Pihl, J. (2011). Literacy education and interprofessional collaboration. Professions and professionalism, 1(1).

Robinson, V., Claire, A., Rowe, L., \& Rowe, K. (2008). The Impact of Leadership on Student Outcomes: An Analysis of the Differential Effects of Leadership Types. Educational Administration Quarterly, 44, 635-676. http://dx.doi.org/10.1177/0013161X08321509

Ryan, J. (2006). Inclusive Leadership. San Francisco, SF: Jossey-Bass.

Røvik, K. (2007). Trender og translasjoner. Oslo: Universitetsforlaget.

Sandberg, N., \& Aasen, P. (2008). Det nasjonale styringsnivået Intensjoner, forventninger og vurderinger Delrapport I Evaluering av Kunnskapslфftet. Oslo: NIFU STEP (Norsk institutt for studier av innovasjon, forskning og utdanning). 
Shields, C. (2003). Good intentions are not enough: Transformative leadership for communities of difference. Lanham, MD:Scarecrow.

Shields, C. (2010). Transformative leadership: Working for equity in diverse contexts. Educational Administration Quarterly, 46(4), 558-589. http://dx.doi.org/10.1177/0013161X10375609

Shields, C. (2011). Transformative Leadership. A Reader. New York, NY:Peter Lang.

Shields, C. (2011). Transformative Leadership: An Introduction. In Shields, C. (Ed). Transformative Leadership A Reader (p1-17). New York, NY, Peter Lang.

Shields, C., Bishop, R., \& Mazawi A.E. (2005). Pathologizing practices. New York, NY: Lang.

Smith, J., Flowers, M., \& Larkin, M. (2009). Interpretative Phenomenological Analysis: Theory, Method and Research Thousand Oaks, CA: SAGE Publications Inc.

Stray, J. H. (2010). Demokratisk medborgerskap i norsk skole?: en kritisk analyse. Universitetet i Oslo: Unipub.

Theoharis, G. (2007). Social Justice educational leaders and resistance:Toward a theory of social justice leadership. Education Administration Quarterly, 43(2), 221-258. http://dx.doi.org/10.1177/0013161X06293717

Thrupp, M., \& Lupton, R. (2006). Taking school contexts more seriously: The social justice challenge. British Journal of Educational Studies, 54(3), 308-328. http://dx.doi.org/ 10.1111/j.1467-8527.2006.00348.x

Tolo, A. and Lillejord, S. (2006). Ledelse i en multikulturell skole. Norsk pedagogisk tidsskrift - forum for pedagogikk og fagdidaktikk, 2, 20-131.

Utdanningsdirektoratet (2010). Evaluering av implementeirng av nye lareplaner i grunnleggnede norsk og morsmål for språklige minoriteter. Oslo: Statens forvaltningstjeneste.

Valencia, R. (1997). The evolution of deficit thinking. London: Falmer Press.

Watkins, J. (2000). Leading via caring-healing: The fourfold way toward transformative leadership. Nursing Administration Quarterly, 25(1), 1-6.

Weiner, E. J. (2003). Secretary Paulo Freire and the democratization of power: Toward a theory of transformative leadership. Educational Philosophy and Theory, 35(1), 89-106. http://dx.doi.org/10.1111/1469-5812.00007

\section{(cc) $\mathrm{BY}$}

This work is licensed under a Creative Commons Attribution 3.0 License. 